\title{
Digestive System Large Cell Neuroendocrine Carcinoma
}

National Cancer Institute

\section{Source}

National Cancer Institute. Digestive System Large Cell Neuroendocrine Carcinoma. NCI

Thesaurus. Code C154617.

An aggressive, high-grade and poorly differentiated carcinoma with neuroendocrine

differentiation that arises from any part of the gastrointestinal system. It is characterized by the presence of malignant large cells. 